\title{
PERLINDUNGAN HUKUM BAGI PASIEN PADA TINDAKAN OPERASI DALAM PERSETUJUAN TINDAKAN MEDIS (INFORMED CONSENT)
}

\author{
Santi Novia Ayu Kurniawati \\ Universitas Sebelas Maret \\ E-mail: santinoviayu@student.uns.ac.id
}

\begin{abstract}
This research aims to determine the agreement for surgery based on informed consent and legal protection for patients in surgery in an informed consent. This research uses empirical legal research. The results of this study were that before the operation was performed, the hospital provided a medical action agreement document based on the informed consent which had to be signed by the patient and / or family as the person in charge and 2 witnesses, namely from the family and the hospital. The agreement document based on informed consent consists of 2 parts, namely the provision of information and consent to medical action. Mistakes made by doctors are the responsibility of the hospital. This is because the hospital is a government hospital and doctors who work are permanent doctors.
\end{abstract}

Keywords: legal protection, surgery, informed consent

\begin{abstract}
Abstrak
Penelitian ini bertujuan untuk mengetahui perjanjian tindakan operasi atas dasar informed consent dan perlindungan hukum bagi pasien pada tindakan operasi dalam persetujuan tindakan medis (informed consent). Penelitian ini menggunakan jenis penelitian hukum empiris. Hasil dari penelitian ini adalah sebelum dilakukan tindakan operasi, pihak rumah sakit memberikan dokumen perjanjian tindakan kedokteran atas dasar informed consent yang harus ditanda tangani oleh pasien dan atau keluarga sebagai penanggung jawab dan 2 orang saksi yaitu dari pihak keluarga dan rumah sakit. Dokumen perjanjian atas dasar informed consent terdiri dari 2 bagian yaitu pemberian informasi dan persetujuan tindakan kedokteran. Kesalahan yang dilakukan oleh dokter merupakan tanggung jawab pihak rumah sakit. Hal ini dikarenakan Rumah Sakit merupakan rumah sakit pemerintah dan dokter yang bekerja merupakan dokter tetap.
\end{abstract}

Kata Kunci: perlindungan hukum, tindakan operasi, informed consent

\section{A. Pendahuluan}

Hubungan hukum perdata terjadi di semua bidang, dan salah satunya adalah perjanjian yang dilakukan untuk memperjelas dan mempertegas hubungan antara dua pihak atau lebih. ${ }^{1}$ Subjek hukum terkait hukum kedokteran, melibatkan dokter dan pasien sebagai subjek hukum, keduanya membentuk baik hubungan medis maupun hubungan hukum. Pelaksanaan tindakan medis harus memperoleh persetujuan pasien atau keluarganya, diwujudkan dalam bentuk dokumen informed consent. ${ }^{2}$

1 Realita Friska. Implementasi Persetujuan Tindakan Medis (Informed Consent) pada Kegiatan Bakti Sosial Kesehatan di Rumah Sakit Islam Sultan Agung Semarang. Jurnal Involusi Kebidanan. 2014. Jakarta, hlm. 26.

2 Samino. Analisis Pelaksanaan Informed Consent. Jurnal Kesehatan. 2014. Jakarta, hlm. 71. 
Jadi, dengan kata lain informed consent adalah persetujuan yang diberikan oleh pasien atau keluarganya atas dasar informasi dan penjelasan mengenai tindakan medis yang akan dilakukan terhadap pasien tersebut. Informed consent menjadi bentuk komunikasi antara dokter dan petugas medis, serta memberi waktu kepada pasien untuk bertanya, menyetujui, atau menolak penanganan tersebut. Hukum Kedokteran atau Medikal Law adalah bagian dari Hukum Kesehatan dengan ruang lingkup yang hanya meliputi bidang medis, yaitu dokter dan orang-orang dibawah kendalinya yang meliputi bidang hukum pidana, perdata, maupun administratif. ${ }^{3}$

Berdasarkan hak, maka setiap pasien mempunyai hak untuk mengetahui prosedur perawatan bagaimana yang akan dialaminya, termasuk risiko yang harus ditanggungnya sebagai akibat metode perawatan tertentu. Kecuali itu pasien juga mempunyai hak untuk mengetahui apakah ada alternatif-alternatif lain, termasuk pula resikonya.

Penandatanganan formulir informed consent secara tertulis hanya merupakan pengukuhan atas apa yang telah disepakati sebelumnya. Tujuan penjelasan yang lengkap adalah agar pasien menentukan sendiri keputusannya sesuai dengan pilihan dia sendiri (informed decision). Oleh karena itu, pasien juga berhak untuk menolak tindakan medis yang dianjurkan. Pasien juga berhak untuk meminta pendapat dokter lain (second opinion), dan dokter yang merawatnya.

Kewajiban memberikan penjelasan atau informasi kepada pasien adalah penanggung jawab perawatan terhadap pasien tersebut, misalnya seorang dokter. Dalam keadaankeadaan tertentu dokter tersebut dapat mendelegasikan wewenangnya kepada tenaga kesehatan lain, akan tetapi tanggung jawab hukum tetap ada padanya.

Secara yuridis, seorang perawat sebenarnya tidak berwenang melaksanakan proses "informed consent". Hal ini menjadi tugas dokter, dan kalau ada pendelegasian wewenang, maka dokter harus yakin benar bahwa perawat yang diberi tugas benar-benar menguasai masalah dan mampu memberikan penjelasan yang dipahami oleh pasien. Oleh karena itu dari sudut hukum tanggung jawab mengenai "informed consent" tetap ada pada dokter. ${ }^{4}$

Dalam hukum, tanggung jawab berarti "keterikatan", manusia sejak dilahirkan memiliki hak dan kewajiaban hal tersebut merupakan anugerah dari Sang Pencipta, karena itu manusia dapat disebut sebagai subyek hukum. Oleh karena itu dokter harus memiliki tanggung jawab sebagai subyek hukum berdasarkan profesinya yang mengemban hak dan kewajiban dokter dan pasien. ${ }^{5}$

Kewajiban hukum dokter yang timbul karena profesinya dan yang timbul dari kontrak terapeutik (penyembuhan) yang dilakukan dalam hubungan dokter dengan pasien. Kewajiban tersebut mengikat setiap dokter yang selanjutnya menimbulkan tanggung jawab hukum bagi diri dokter yang bersangkutan. Dalam menjalakan kewajiban hukumnya, diperlukan adanya ketaatan dan kesungguhan dari dokter tersebut dalam melaksanakan kewajiban sebagai pengemban profesi.

Seorang dokter akan dianggap melakukan kesalahan dalam profesinya, apabila ia tidak memenuhi kewajibannya sebagai petugas medis yang baik, dengan kemampuan

3 Ratman, Desriza. Aspek Hukum Informed Consent dan Rekam Medis Dalam Transaksi Terapeutik. 2013. Bandung: Keni Media, hlm. 15.

4 Soerjono Soekanto. Aspek Hukum Kesehatan. 1989. Jakarta: Penerbit Ind- Hill-Co, hlm. 68.

5 Isfandyarie, Anny. Tanggung Jawab Hukum dan Sanksi Bagi Dokter. 2006. Jakarta: Prestasi Pustaka, hlm 2. 
yang normal yang biasa mengandung suatu persyaratan, bahwa tugas pertama seorang dokter saat menghadapi pasien adalah memberikan diagnosis dan kemudian untuk mencari terapinya. Keberhasilan seorang dokter dalam memberikan diagnosis dan terapi yang baik akan tergantung dari pengetahuan atau ilmu dan kemampuan yang dimilikinya, dan juga diperlukan pengalaman yang ada.

Persetujuan yang ditanda tangani oleh pasien atau keluarga terdekatnya tersebut, tidak membebaskan dokter dari tuntutan jika dokter melakukan kelalaian. Tindakan medis yang dilakukan tanpa persetujuan pasien atau keluarga terdekatnya, dapat digolongkan sebagai tindakan melakukan penganiayaan berdasarkan Pasal 351 KUHP.

Tindakan kedokteran yang diberikan kepada pasien harus mendapat persetujuan, dalam keadaan gawat darurat untuk menyelamatkan jiwa pasien dan/atau mencegah kecacatan tidak diperlukan persetujuan tindakan kedokteran, namun dokter wajib memberikan penjelasan sesegera mungkin setelah pasien sadar atau kepada keluarga terdekat, pemberian persetujuan tindakan medis tidak menghapuskan tanggung gugat hukum dalam hal terbukti adanya kelalaian dalam melakukan tindakan kedokteran yang mengakibatkan kerugian pada pasien.

Dalam hal ini adalah tindakan dokter dan tenaga kesehatan lainnya saat melakukan operasi pada pasien. Seperti yang tertuang dalam informed consent untuk pasien yang akan melakukan operasi. Biasanya dokter tidak akan memberi tahu langsung kepada pasien mengenai kondisi pasien dan penanganan operasi karena ditakutkan jika pasien mengalami syok, maka dari itu dokter memberitahu hanya kepada keluarga/wali (jika pasien belum berusia 21 tahun dan belum menikah) atau memberitahu kepada suami/istri pasien (jika pasien sudah menikah). Kemudian dalam informed consent dinyatakan bahwa keluarga dan pasien tidak bisa menuntut atas apa yang terjadi diatas meja operasi. Jadi disitulah letak bagaimana perlindungan hukum bagi pasien pada tindakan operasi dalam persetujuan tindakan medis (informed consent).

Penelitian ini bertujuan untuk mengetahui perjanjian tindakan operasi atas dasar informed consent dan perlindungan hukum bagi pasien pada tindakan operasi dalam persetujuan tindakan medis (informed consent). Penelitian ini menggunakan jenis penelitian hukum empiris.

\section{B. Pembahasan}

\section{Perjanjian Tindakan Operasi Atas Dasar Informed Consent}

Sebelum dilakukan tindakan operasi, pihak rumah sakit memberikan dokumen perjanjian tindakan kedokteran atas dasar informed consent yang harus ditanda tangani oleh pasien dan atau keluarga sebagai penanggung jawab dan 2 orang saksi yaitu dari pihak keluarga dan rumah sakit. Dokumen perjanjian atas dasar informed consent terdiri dari 2 bagian yaitu pemberian informasi dan persetujuan tindakan kedokteran. Hal ini sudah sesuai dengan Permenkes Nomor 290 Tahun 2008 tentang Persetujuan Tindakan Kedokteran.

Dokumen persetujuan tersebut sekaligus sebagai dokumen perjanjian tindakan kedokteran. Sifat perjanjian ini bersifat mutlak, artinya harus ada (wajib) persetujuan dari pasien atau keluarganya sebelum tindakan operasi dilaksanakan, hal ini sesuai dengan Pasal 2 ayat (1) Permenkes Nomer 290 Tahun 2008 yang menyatakan bahwa 
"Semua tindakan kedokteran yang akan dilakukan terhadap pasien harus mendapat persetujuan. Informed consent tersebut harus diberikan secara benar, jujur serta tidak bermaksud untuk menakut-nakuti atau bersifat memaksa.

Penandatanganan perjanjian ini merupakan pengukuhan apa yang telah disepakati bersama. Dengan menandatangani perjanjian tersebut, maka kedua belah pihak telah bersepakat dengan apa yang ada dalam isi perjanjian dan bersedia memenuhi segala hak dan kewajiban yang timbul setelah perjanjian tersebut. Hal ini sesuai dengan ketentuan yang diatur padalam Pasal 3 ayat (1) Permenkes Nomor 290 Tahun 2008, tentang persetujuan tindakan kedokteran menyatakan bahwa "Setiap tindakan kedokteran yang mengandung risiko tinggi harus memperoleh persetujuan tertulis yang ditandatangani oleh yang berhak memberikan persetujuan".

Bentuk perjanjian tindakan kedokteran pada pasien pada umumnya yang dibuat dalam bentuk tertulis. Perjanjian tindakan kedokteran pada pasien Rumah Sakit merupakan perjanjian baku dikarenakan bentuk dan isi perjanjian ditetapkan secara sepihak yaitu oleh pihak rumah sakit dalam suatu bentuk tertentu (tertulis) yang telah dipersiapkan terlebih dahulu secara massal. Hal tersebut dilakukan untuk mengantisipasi kebutuhan dan kepentingan untuk bertindak cepat dari dokter/rumah sakit dan tetap melindungi para pihak.

Isi dari perjanjian tindakan kedokteran pada pasien di Rumah Sakit memuat adanya keadaan khusus yang harus disepakati untuk dipenuhi. Isi dari perjanjian tersebut meliputi pernyataan persetujuan dari pasien atau keluarganya yang diberikan dengan penuh kesadaran dan tanpa paksaan atas tindakan medis yang akan dilakukan terhadap dirinya, pernyataan bahwa pasien telah mendapatkan penjelasan dari dokter dan mengerti sifat, tujuan, risiko dan perlunya tindakan kedokteran yang akan dilakukan pada pasien yang akan dioperasi.

Selain itu, disertai pula penandatanganan oleh para pihak yang terkait yaitu pasien/keluarganya, dokter operator maupun dokter anastesi serta dua orang saksi yang masing-masing satu orang dari pihak rumah sakit dan satu orang dari pihak pasien. Penandatanganan dilakukan untuk sahnya perjanjian tindakan kedokteran pada pasien, karena berarti kedua belah pihak telah menyetujui hal-hal pokok yang telah diperjanjikan.

Dokter dalam hal ini adalah dokter yang akan melakukan tindakan kedokteran tersebut, atau sering disebut dengan dokter operator. Tetapi apabila dokter berhalangan, maka penjelasan dapat diwakilkan kepada dokter residen yang ditunjuk. Informasi diberikan dengan bahasa yang sederhana dan jelas serta disesuaikan dengan tingkat pendidikan dan intelektual dari pasien, sehingga pasien dapat mengerti dengan jelas.

Ada dua pihak yang bertanda tangan dalam perjanjian tindakan operasi yaitu pihak pasien dan pihak dokter yang mewakili rumah sakit. Dalam pemberian informasi, dokter harus menjelaskan mengenai jalannya penyakit, hal ini bertujuan agar pasien benar-benar mengetahui keadaan yang terjadi pada dirinya. Mengenai pihak yang memberikan penjelasan informed consent adalah dokter.

Perjanjian tentang upaya atau disebut Inspaningsverbintenis bukan perjanjian tentang hasil atau disebut (Resultaatverbintenis). Pada perjanjian tentang upaya maka prestasi yang harus diberikan oleh dokter adalah upaya semaksimal mungkin, 
sedangkan pada perjanjian tentang hasil, prestasi yang harus diberikan oleh dokter berupa hasil tertentu.

\section{Perlindungan Hukum bagi Pasien pada Tindakan Operasi dalam Persetujuan Tindakan Medis (Informed Consent)}

Berdasarkan konsep informed consent yang timbul berdasarkan hubungan antara dokter dengan pasien maka terjalin suatu perjanjian dan masing-masing pihak, baik yang memberikan pelayanan maupun yang menerima pelayanan mempunyai hak dan kewajiban yang harus dihormati. Artinya bahwa di satu pihak dokter mempunyai kewajiban untuk melakukan diagnosis, pengobatan dan tindakan kedokteran yang terbaik menurut jalan pikiran dan pertimbangannya, tetapi pasien atau keluarganya mempunyai hak untuk menentukan pengobatan atau tindakan kedokteran apa yang akan dilakukan terhadap dirinya. Ada dua pihak yang bertanda tangan dalam perjanjian tindakan operasi yaitu pihak pasien dan pihak dokter yang mewakili rumah sakit.

Berkaitan dengan pertanggungjawaban pihak rumah sakit atas kesalahan/kelalaian yang dilakukan dokter terhadap pasien, maka rumah sakit bertanggungjawab terhadap masalah hukum yang dilakukan oleh dokter, karena dokter merupakan tenaga kesehatan Rumah Sakit. Hal ini sesuai dengan pasal 46 Undang-Undang RI Nomor 44 Tahun 2009 Tentang Rumah Sakit, disebutkan bahwa: "Rumah Sakit bertanggung jawab secara hukum terhadap semua kerugian yang ditimbulkan atas kelalaian yang dilakukan oleh tenaga kesehatan di Rumah sakit”.

Kesalahan yang dilakukan oleh dokter di Rumah Sakit merupakan tanggung jawab pihak rumah sakit. Hal ini berlaku bagi Rumah Sakit Negeri yang merupakan Rumah Sakit pemerintah dan dokter yang bekerja merupakan dokter in atau dokter tetap. Berdasarkan hal tersebut, maka dokter bekerja untuk dan atas nama rumah sakit, sehingga jika terjadi tuntutan dari pasien atas kesalahan yang dilakukan dokter, maka rumah sakit yang bertanggung jawab atas tindakan dari dokter tersebut, dan segala ganti kerugian yang diderita pasien merupakan tanggung jawab pihak rumah sakit. Hal ini sesuai dengan pasal 46 Undang- Undang RI Nomor 44 Tahun 200 Tentang Rumah Sakit.

Mengenai kesalahan dengan tingkat kerugian pasien yang cukup besar, adalah adanya seorang pasien yang meninggal atau mengalami cacat permanen yang tidak dapat disembuhkan. Maka dalam hal besar kecil, bentuknya dan sejauh mana penggantian kerugian tersebut, rumah sakit akan mendiskusikan lebih lanjut dengan komite medik mengenai kesalahan yang dilakukan oleh dokter tersebut.

Dalam hal ini, maka rumah sakit dalam hal pertanggungjawaban jika terjadi kesalahan dalam pelaksanaan perjanjian tindakan kedokteran, kepastian tersebut didapatkan setelah pihak rumah sakit mendiskusikan bersama dengan komite medik. Dari hasil musyawarah atau diskusi tersebut maka pihak rumah sakit akan memberikan penggantian kerugian atas kesalahan/kelalaian yang dilakukan oleh dokter dalam pelaksanaan perjanjian tindakan kedokteran.

Berkaitan dengan kelalaian yang dilakukan oleh dokter yang bekerja di rumah sakit, maka rumah sakit akan mengkonsultasikan tindakan kesalahan yang dilakukan oleh dokter tersebut kepada IDI (Ikatan Dokter Indonesia), apakah tindakan tersebut harus mendapat sanksi tertentu atau tidak. Hal ini dikarenakan seluruh dokter bernaung di 
bawah Ikatan Dokter Indonesia. Sanksi tersebut disesuaikan dengan jenis pelanggaran yang dilakukan oleh dokter tersebut. Dalam hal malpraktek etik, IDI telah mempunyai Majelis Kehormatan Etik Kedokteran (MKEK), baik di tingkat pusat maupun tingkat cabang serta Panitia Pertimbangan dan Pembinaan Etik Kedokteran (P3EK) yang terdapat pula di pusat dan di tingkat provinsi.

Hubungan antara dokter dengan pasien termasuk dalam perjanjian untuk melakukan beberapa jasa dan karena sifat hubungan hukumnya yang khusus yaitu Inspanning Verbintenis (perjanjian tentang upaya), sehingga dokter dalam hal ini berkewajiban untuk melakukan upaya semaksimal mungkin. Secara hukum hubungan antara dokter dan pasien merupakan suatu hubungan ikhtiar atau usaha maksimal.

Pada perikatan ikhtiar maka prestasi yang harus diberikan oleh dokter adalah upaya semaksimal mungkin. Dokter tidak pernah menjanjikan kesembuhan, akan tetapi berikhtiar sekuatnya agar pasien sembuh, sehingga sangat sulit untuk menentukan bahwa dokter melakukan kesalahan. Umumnya jika terjadi sesuatu yang di luar kehendak, maka dokter menyatakan bahwa mereka telah berusaha semaksimal mungkin.

Pasien secara yuridis tidak dapat diidentikkan dengan konsumen, hal ini karena hubungan yang terjadi di antara dokter dan pasien bukan merupakan hubungan jualbeli yang diatur dalam KUHPerdata, melainkan hubungan antara dokter dengan pasien hanya merupakan bentuk perikatan medik, yaitu perjanjian "usaha" (inspanning verbintenis) tepatnya perjanjian usaha kesembuhan (teraupetik), bukan perikatan medik "hasil" (resultaat verbintenis), disamping itu profesi dokter dalam etika kedokteran masih berpegang pada prinsip "pengabdian dan kemanusiaan", sehingga sulit disamakan antara pasien dengan konsumen pada umumnya.

Berdasarkanuraiandiatas, perjanjiantentangupayaataudisebutInspaningsverbintenis bukan perjanjian tentang hasil atau disebut (Resultaatverbintenis). Pada perjanjian tentang upaya maka prestasi yang harus diberikan oleh dokter adalah upaya semaksimal mungkin, sedangkan pada perjanjian tentang hasil, prestasi yang harus diberikan oleh dokter berupa hasil tertentu.

Hubungan hukum inspaning verbintenis antara dua subjek hukum (dokter dan pasien) tidak menjanjikan suatu kesembuhan atau kematian, karena obyek dari hubungan hukum itu adalah berupaya secara maksimal yang dilakukan secara hati-hati dan cermat sesuai dengan surat persetujuan tindakan medik berdasarkan ilmu pengetahuan dan pengalamannya dalam menangani penyakit tersebut, sehingga apabila terjadi kegagalan atau komplikasi dalam melakukan operasi maka hal tersebut merupakan tanggung jawab yang dipikul antara dokter dan pasien. Dokter tidak dipersalahkan oleh karena dokter telah berusaha keras untuk menyembuhkan pasien atau mengupayakan berhasilnya tindakan operasi.

Tanggung jawab dokter yang menangani operasi baru muncul apabila dokter yang melakukan operasi tersebut melakukan kesalahan (mall practice) yang mengakibatkan kerugian pada pihak pasien. Pada dasarnya untuk menuntut tanggung jawab dokter yang mengoperasi karena kesalahan yang mengakibatkan kerugian bagi pasien ada 2 macam yaitu: tanggung jawab atas kerugian yang didasarkan karena wanprestasi dan tanggung jawab dokter atas kerugian yang disebabkan karena perbuatan melawan hukum. 
Oleh karena itu pasien dapat minta pertanggungjawaban rumah sakit jika pasien/ keluarga merasa dirugikan akibat kelalaian atau tidak hati-hati dalam melakukan operasi di Rumah Sakit. Dikarenakan Rumah Sakit Negeri adalah Rumah Sakit milik pemerintah maka Rumah Sakit pemerintah dapat dituntut berdasarkan Pasal 1366 KUHPerdata karena dokter yang melakukan operasi tersebut adalah pegawai yang bekerja pada Rumah Sakit pemerintah adalah pegawai negeri dan negara sebagai suatu badan hukum. Untuk itu Rumah Sakit pemerintah dapat dituntut untuk membayar ganti rugi atas tindakan pegawainya, yaitu dokter yang melakukan operasi yang merugikan pasien

Hubungan antara dokter dengan pasien termasuk dalam perjanjian untuk melakukan beberapa jasa dan karena sifat hubungan hukumnya yang khusus yaitu Inspanning Verbintenis (perjanjian tentang upaya), sehingga dokter dalam hal ini berkewajiban untuk melakukan upaya semaksimal mungkin. Secara hukum hubungan antara dokter dan pasien merupakan suatu hubungan ikhtiar atau usaha maksimal. Pada perikatan ikhtiar. Maka prestasi yang harus diberikan oleh dokter adalah upaya semaksimal mungkin. Dokter tidak pernah menjanjikan kesembuhan, akan tetapi berikhtiar sekuatnya agar pasien sembuh, sehingga sangat sulit untuk menentukan bahwa dokter melakukan kesalahan. Umumnya jika terjadi sesuatu yang di luar kehendak, maka dokter menyatakan bahwa mereka telah berusaha semaksimal mungkin.

Tanggung jawab dokter yang menangani operasi baru muncul apabila dokter yang melakukan operasi tersebut melakukan kesalahan (mall practice) yang mengakibatkan kerugian pada pihak pasien. Pada dasarnya untuk menuntut tanggung jawab dokter yang mengoperasi karena kesalahan yang mengakibatkan kerugian bagi pasien ada 2 macam yaitu: tanggung jawab atas kerugian yang didasarkan karena wanprestasi dan tanggung jawab dokter atas kerugian yang disebabkan karena perbuatan melawan hukum.

Oleh karena itu pasien dapat minta pertanggungjawaban rumah sakit jika pasien/ keluarga merasa dirugikan akibat kelalaian atau tidak hati-hati dalam melakukan operasi di Rumah Sakit. Hal ini dikarenakan Rumah Sakit Negeri adalah Rumah Sakit milik pemerintah maka Rumah Sakit pemerintah dapat dituntut berdasarkan Pasal 1366 KUHPerdata karena dokter yang melakukan operasi tersebut adalah pegawai yang bekerja pada Rumah Sakit pemerintah adalah pegawai negeri dan negara sebagai suatu badan hukum. Untuk itu Rumah Sakit pemerintah dapat dituntut untuk membayar ganti rugi atas tindakan pegawainya, yaitu dokter yang melakukan operasi yang merugikan pasien.

Perlindungan hukum terhadap pasien yang terlibat dalam Informed Consent pada tindakan operasi, terdapat pada tanggung jawab masing-masing atas hak dan kewajiban. Dalam perjanjian terapeutik, apa yang menjadi hak pasien seharusnya menjadi kewajiban tenaga kesehatan (dokter), dan apa yang menjadi hak tenaga kesehatan (dokter) seharusnya menjadi kewajiban pasien. Informed Consent merupakan hal penting dalam perjanjian terapeutik, karena dapat memberikan manfaat bagi dokter maupun bagi pasien.

Kesalahan yang dilakukan oleh dokter merupakan tanggung jawab pihak rumah sakit. Hal ini dikarenakan Rumah Sakit merupakan rumah sakit pemerintah dan dokter yang bekerja merupakan dokter in atau dokter tetap. Berdasarkan hal tersebut, maka dokter bekerja untuk dan atas nama rumah sakit, sehingga jika terjadi tuntutan dari 
pasien atas kesalahan yang dilakukan dokter, maka rumah sakit yang bertanggung jawab atas tindakan dari dokter tersebut, dan segala ganti kerugian yang diderita pasien merupakan tanggung jawab pihak rumah sakit. Hal ini sesuai dengan Pasal 46 UndangUndang RI Nomor 44 Tahun 2009 Tentang Rumah Sakit.

\section{Kesimpulan}

Perjanjian tentang upaya atau disebut Inspaningsverbintenis bukan perjanjian tentang hasil atau disebut (Resultaatverbintenis). Pada perjanjian tentang upaya maka prestasi yang harus diberikan oleh dokter adalah upaya semaksimal mungkin, sedangkan pada perjanjian tentang hasil, prestasi yang harus diberikan oleh dokter berupa hasil tertentu.

Perlindungan hukum terhadap pasien yang terlibat dalam Informed Consent pada tindakan operasi, terdapat pada tanggung jawab masing-masing atas hak dan kewajiban. Dalam perjanjian terapeutik, apa yang menjadi hak pasien seharusnya menjadi kewajiban tenaga kesehatan (dokter), dan apa yang menjadi hak tenaga kesehatan (dokter) seharusnya menjadi kewajiban pasien. Informed Consent merupakan hal penting dalam perjanjian terapeutik, karena dapat memberikan manfaat bagi dokter maupun bagi pasien.

Kesalahan yang dilakukan oleh dokter merupakan tanggung jawab pihak rumah sakit.

Hal ini dikarenakan Rumah Sakit merupakan rumah sakit pemerintah dan dokter yang bekerja merupakan dokter in atau dokter tetap. Berdasarkan hal tersebut, maka dokter bekerja untuk dan atas nama rumah sakit, sehingga jika terjadi tuntutan dari pasien atas kesalahan yang dilakukan dokter, maka rumah sakit yang bertanggung jawab atas tindakan dari dokter tersebut, dan segala ganti kerugian yang diderita pasien merupakan tanggung jawab pihak rumah sakit. Hal ini sesuai dengan Pasal 46 Undang-Undang RI Nomor 44 Tahun 2009 Tentang Rumah Sakit.

\section{Daftar Pustaka}

\section{Buku}

Isfandyarie, Anny. Tanggung Jawab Hukum dan Sanksi Bagi Dokter. 2006. Jakarta: Prestasi Pustaka.

Ratman, Desriza. Aspek Hukum Informed Consent dan Rekam Medis Dalam Transaksi Terapeutik. 2013. Bandung: Keni Media.

Soerjono Soekanto. Aspek Hukum Kesehatan. 1989. Jakarta: Ind- Hill-Co.

Soerjono Soekanto. Pengantar Penelitian Hukum. 2008. Jakarta: UI Press.

\section{Jurnal}

Realita Friska. Implementasi Persetujuan Tindakan Medis (Informed Consent) pada Kegiatan Bakti Sosial Kesehatan di Rumah Sakit Islam Sultan Agung Semarang. 2014. Jurnal Involusi Kebidanan. Jakarta.

Samino. Analisis Pelaksanaan Informed Consent. 2014. Jurnal Kesehatan. Jakarta. 